\title{
Ideological Differences between America and China from Perspectives of Transitivity System -Illustrated by Trump's and Xi Jinping's Presidential Inaugural Addresses
}

\author{
Guohai Liao \\ College of Foreign Languages, University of Shanghai for Science and Technology, Shanghai 200093, China \\ Geling Han \\ College of Foreign Languages, University of Shanghai for Science and Technology, Shanghai 200093, China
}

\begin{abstract}
Taking Systemic Functional Grammar proposed by M.A.K. Halliday as theoretical framework, this paper is set to quantitatively analyze Donald Trump's inaugural address and Xi Jinping's first public speech as president of China in the distribution and functions of six processes from perspectives of transitivity system. Having done this, ideological differences between America and China beneath the textual discourse of their speeches will be qualitatively illustrated. It finds that material, mental and relational processes predominate both speeches and Xi's speech mainly takes the overall lead in spiritual guidance and inclines to generally control the economic and social development in China. For Trump, he needs to employ all his skill to induce and gain the supports from American people, objectively depicting American mediocre situations by material process, trying to narrow down the psychological distance between his governance and the people by mental process and increasing the belonging of American people by relational process.
\end{abstract}

Index Terms - transitivity system, inaugural addresses, political ideologies, process type, systemic functional grammar

\section{INTRODUCTION}

Donald Trump became the 45th president of the United States, on January 20, 2017, and later delivered his inaugural speech. As a president without having any administrative experience, his inauguration speech has aroused widespread attention and concerns in society. Meanwhile, in China, President Xi jinping made his public speech debut in the $12^{\text {th }}$ national people's congress after his inauguration in May 17, 2013. The inaugural speeches of the presidents in United States have consistently the focus of political life. In the speeches, presidents of U.S. commemorate the country's past, look for the future and strive to set the stress on the future term, while riveting enough attention to the present. For China, public addresses released by Presidents or other administrative leaders will also herald future plans, political intentions, the basic principles of governing the country. American president Trump inaugural address and china's President Xi's first speech debut are kindred and congenial. They are both political speech covering all aspects of China and the United States. However, there have been so far relatively few comparative studies on the political speeches between China and America.

Systemic Functional Grammar can be applied to miscellaneous styles to reveal implicit meaning of texts or discourses and conversations. As a sub-system of ideational metafunctionin Systemic Functional Grammar, the transitivity system is considered to be an effective discourse analysis model. Halliday (1971) first analyzed William Golding's famous novel The Inheritors, becoming the pioneer in textual analysis using transitivity system. From them on, transitivity system is used by a quite number of scholars from at home and abroad to analyze different text genres, such as literary works, advertisements, news reports and forensic and political discourses (Shen, 2006; Gong, 2006; Yang,2004). Wellman Kondowe (2014) used transitivity theory to investigate the Bingu wa Mutharika's inaugural address, condemning his autocratic and dictatorship leadership ideologies. China scholar Chen yin (2008) and Wang li(2009) analyze the presidents Bush's and Obama's inaugural addresses respectively. Li Min (2010) in China does the comparative study on Roosevelt and Obama's addresses. Wen li (2013) collectively probe into the distributions and function of six transitivity processes in speeches from several American presidents. It is clearly established that previous studies have seldom given attention to the comparative analyses between China and America, that is, Chinese and English, mainly focusing on the intra-language on some populous textual styles, such as literary works, advertisements. This paper investigates how six transitivity processes are achieved in Trump's and Xi Jinping's inaugural addresses and what differences of the distributions and functions of them Trump's and Xi Jinping's addresses exist in hope of finding the ideological differences between China and the United States as transitivity system as 
theoretical model.

\section{THEORETICAL FRAMEWORK}

Based on Systemic Functional Grammar's claims, language is a product of social activities. Language carries an array of functions. Halliday (1994) classified language's metafunctions into 3 types: ideational function, interpersonal function and textual function. In their view, Clause, the basic unit in text for Systemic Functional Grammar, can be regard as a representation which models experience of change (Halliday, 1994). "And experientially, the clause construes a quantum of change as a figure, or configuration of a process, participants involved in it and any attendant circumstances. (Halliday, 2004, p.169)" A figure refers a figure of happening, doing, sensing, saying, being or having (Halliday, 2004). All such figures are sorted out in the grammar of the clause which can reflect a mode of action, of giving and demanding goods and services and information (Halliday, 2004). "The grammatical system by which this is achieved is that of TRANSITIVITY. The transitivity system construes the world of experience into a manageable set of PROCESS TYPES (Halliday, 2004, p.170)." Each process type embodies it own model or schema for providing a particular domain of experience as a figure of a particular kind (Halliday, 2004). Process types can be classified into 6 kinds: material process, mental process, relational process, behavioral process, verbal process and existential process.

M.A.K. Halliday argued (2004) that the clauses of material process and that of mental process are the fact that the grammar sets up a discontinuity between these two (out experience and inner experience): it distinguishes rather clearly between out experience [going on 'out there'], the processes of the external world, and inner experience [going on inside ourselves; including perception, emotion and imagination], the process of consciousness. The grammatical categories are those of material process clauses and mental process clauses. Material process is a process of doing and happening, specifically, transitive doing and intransitive happening. "Doing" process is realized by transitive verbs while "happening" process is realized by intransitive verbs. Material process includes participants, like actor, goal, scope, recipient, client, and attribute. Material process also can be concrete and abstract. Changes in the material world that can be perceived and changes in physical world make up concrete material process. However, such concrete material processes have also come to serve as a model for construing our experience of change in abstract phenomena (Halliday, 2004). Material process can be creative clauses, where the Actor or Goal is construed as being brought into existence as the process unfolds, or transformative ones, where a pre-existing Actor or Goal is construed as being transformed as the process unfold (Halliday, 2004). The outcome of the transformation is an elaboration, extension or enhancement of the Actor (intransitive) or Goal(transitive) (Halliday, 2004).

Mental process is a process of sensing, which has four sub-types: perception, affection, cognition, and desideration. Participants involved in a mental process are senser and phenomenon. Relational processes are processes of being, which refers to a kind of relation between entities. It can be further divided into attributive type or identifying type. The former type aims to describe things while the latter one tries to define some entities. On the borderline between material and mental are behavioral processes which refer to those that represent the outer manifestations of inner workings, the acting out of processes of consciousness and physiological states, like coughing, laughing, breathing, etc (Halliday, 2004). Verbal process refers to a process of saying which is a symbolic relationships construed in human consciousness and enacted in the form of language, like saying and meaning (Halliday, 2004). The central participant is sayer and the content of say is verbiage. Existential process is a process regarding existence, the existential, by which all phenomena are simply tended to happen or exist.

\section{RESEARCH METHOD}

\section{A. Research Data}

The research data used in this paper are two Presidents inaugural addresses. Due to the political differences in regime, China does not have inaugural addresses. Therefore, President Xi jinping's first public speech in the $12^{\text {th }}$ national people's congress after inauguration is adopted. The two public speech are kindred and congenial, and both are from government official website. The tokens of inaugural address of Trump are 1476, and the words of first public speech from President Xi are 3078.

\section{B. Research Questions}

This paper aims to do a transitivity analysis of Trump's and Xi jinping's inaugural addresses to try to answer the following questions:

1. What are the distribution and differences of six transitivity processes in Trump's and Xi's inaugural speeches?

2. What are the differences of functions and ideologies the six transitivity processes try to present in Trump's and Xi's addresses of inauguration?

\section{Research Procedure}

The research method used in this paper is mixed method, that is, qualitative method plus quantitative method. Quantitative method is used to demonstrate the distributions and features of six processes by statistical tables in Trump's and Xi's speeches. And then qualitative method is adopted to analyze and explain the functions of each 
transitivity process. The research, specifically, follows the 4 procedures. First, the number of clauses needed to be analyzed is determined. Second, based on the criteria for distinguishing process types proposed by Halliday (2004), the process type of each clause is analyzed. Third, the process types of all clauses are manually labelled and the research calculates the total number of each type of process as a percentage compared with the total number of analyzed clauses. The distribution of the six process types in Trump's and Xi's speeches is illustrated by table form in hope of finding their similarities or differences. Last, having done quantitative analysis, the functions of the six processes in texts will be qualitatively analyzed to interpret their ideological differences on the ground of the social and historical background between China and America.

\section{RESULTS AND DISCUSSION}

\section{A. The Distributions and Characteristics of Six Transitivity Processes in Trump's and Xi's Addresses}

TABLE I.

THE DISTRIBUTION OF THE SIX TRANSITIVITY PROCESSES IN TRUMP'S AND XI'S SPEECHES
\begin{tabular}{|c|c|c|c|c|}
\hline \multirow{2}{*}{ Process Type } & \multicolumn{2}{|c|}{ Trump's Inaugural Address } & \multicolumn{2}{|c|}{ Xi's First Public Speech } \\
\cline { 2 - 5 } & Frequency & Percentage $(\%)$ & Frequency & Percentage $(\%)$ \\
\hline Material & 99 & 69.7 & 40 & 67.7 \\
\hline Relational & 27 & 19.1 & 16 & 27.1 \\
\hline Mental & 7 & 4.9 & 2 & 3.3 \\
\hline Verbal & 1 & 0.7 & 0 & 0 \\
\hline Existential & 5 & 3.5 & 0 & 0 \\
\hline Behavioral & 3 & 2.1 & 1 & 1.6 \\
\hline Total & 142 & 100 & 59 & 100 \\
\hline
\end{tabular}

As can be seem from Table 1, the overall distribution of material processes in the inauguration speeches of President Trump and President Xi is similar. In the two inaugural speeches, the material processes predominantly occur, 99 times in Trump's speech and 40 times in Xi's speech, accounting for $69.7 \%$ and $67.7 \%$ respectively. Secondly, the relational processes are 27 times in Trump's speech and 16 times in Xi's speech, up to $19.1 \%$ and 27.1\% respectively. The number of relational processes in Xi's speech surpasses the number of those in Trump's speech. The distribution of mental processes in these two speeches is akin, up to $4.9 \%$ in Trump's Speech and 3.3\% in Xi's speech. There is no verbal process in Xi's speech, but only one verbal process in Trump's speech. Existential process can not be found in Xi's speech, but 5 times, up to $3.5 \%$ of distribution of it in Trump's speech. Behavioral processes are quite rare to find in the two speech texts, 3 times, accounting for $2.1 \%$ in Trump's speech and one behavioral process, just up to $1.6 \%$ in Xi's speech.

Although there are similarities in the distribution of the six transitivity process types in the two speech texts, there exist some differences. Verbal process, existential and behavioral process are not used frequently in Xi's speech, while these processes can be found in Trump's speech, especially, existential processes, up to 3.5\% of the total in Trump's speech. Overall, the last 3 processes, that is, verbal, existential, and behavioral processes are seldom used in the two speech texts.

\section{B. The Functions of Six Transitivity Processes in Trump's and Xi's Addresses}

\section{Material process}

From Table 2, it is obviously established that in the inauguration speeches of two presidents, Trump and $\mathrm{Xi}$, the material processes have the highest occupation of occurrences in both speeches, accounting for more than $60 \%$ of the overall processes. This shows that the two presidents are all concerned with the "doing" things, focusing concrete things instead of taking the talk. As new presidents, both Trump and $\mathrm{Xi}$, are inclined to show their ability to handle state affaires and echo people's empathy to advance the development of their countries. Material process is a good choice for them to demonstrate practical practice concerns. However, there are also subtle differences in their speeches in using material process.

For Trump, most material processes are used to depict the present political and economical specific situations in America and profoundly illustrate the efforts the new government will take. He uses material process to show his sincerity and practical practices and tries to narrow down the distance between his government and the public. However, material processes in Xi's first public speech mostly focus on the implementation of major policies, thoughts and tend to encourage people's actions on advancing China's development and educate people from a more superior stance and an overall ideological and spiritual perspective.

Example 1: Washington flourished, but the people did not share in its wealth. Politicians prospered, but the jobs left. And the factories closed. The establishment protected itself but not the citizens of our country. (The Inaugural address by President Donald Trump)

In Example 1, Trump uses material processes to depict present bleak and dismal American situationsin the filed of 
income, job problems and political issues. The verbs "flourish, share, prosper, left, close and protect" physically show Trump's determination in bringing America economy back on the track, making his speech more convincing and promising.

Example 2: 全国各族人民一定要弘扬伟大的民族精神和时代精神, 不断增强团结一心的精神纽带、自强不息 的精神动力, 永远朝气蓬勃迈向未来。(The First Public Speech by President Xi Jinping)

In Example 2, Xi's material processes more concentrate on the mental activities in people's mind from an ideological aspect instead of physical world depiction in China.

Example 3: We, the citizens of America, are now joined in a great national effort to rebuild our country and restore its promise for all of our people. (The Inaugural address by President Donald Trump)

In trump's speech, the personal pronounce "we" is used for the Trump's government and American people, which can narrow down psychological distance between the administration and the public and make people feel their stance also shared by their government. The verbs "restore and rebuild" indeed cares people's interests.

Example 4: 我们要坚持党的领导、人民当家作主、依法治国有机统一......我们要坚持发展是硬道理的战略思想, 坚持以经济建设为中心...我们要巩固和发展最广泛的爱国统一战线，加强中国共产党同....... (The First Public Speech by President Xi Jinping)

Example 5: We will bring back our jobs. We will bring back our borders. We will bring back our wealth, and we will bring back our dreams. We will build new roads and highways and bridges and airports and tunnels and railways all across our wonderful nation. We will get our people off of welfare and back to work rebuilding our country with American hands and American labor....(The Inaugural address by President Donald Trump)

According to Example 4 and 5, Trump and Xi both use the personal pronounce "we" and "我们” in material processes. Halliday(2004) claims that the pronounce "we" as actor traditionally relate to inclusiveness in ideologies. Personal pronounces "We" and “我们” as actor account for 28.4\% in Trump's material processes and 27.5\% in Xi's material processes. This shows that in material processes of public speeches, inclusiveness is more preferred. The differences between the two speeches in material processes are that Trump more focuses on specific areas concerning people's life such as transportation, job, and welfare, and while $\mathrm{Xi}$ more intends to the intensification and implementation of socialism spirits and thoughts.

2. Relational process

As is illustrated in the Table 2, relational process holds the second place in the distribution of the six transitivity processes, which accounts for 19.1\% in Trump's speech and 27.1\% in Xi's speech. Although it is far below material process, relational process occurs much more frequently than the other four processes. Trump's relational processes mainly focus on attributive type of relational process, physically depicting American situations and proposing a new blue print for American people and American development. Relational processes of identifying type in Trump's speech identify the country belonging to their people, tending to narrow down the psychological distance between the new government and American people. However, Xi's relational processes concentrate on relational processes of identifying type, mainly clarifying and defining the boundary of spiritual ideologies.

Example 6: When America is united, America is totally unstoppable. (The Inaugural address by President Donald Trump)

In Example 6, it describes the future characteristics of America if unity features America.

Example 7: What truly matters is not which party controls our government but whether our government is controlled by the people. (The Inaugural address by President Donald Trump)

Example 8: It belongs to everyone gathered here today and everyone watching all across America. This is your day. This is your celebration. And this, the United States of America, is your country. (The Inaugural address by President Donald Trump)

Example 7 and 8 manage to identify the belonging of America and try to bridge down the mental distance between the country and its people. Based on this, Trump, to some extend, make American people restore their confidence to build their country.

Example 9:这种精神是凝心聚力的兴国之魂、强国之魄。(The First Public Speech by President Xi Jinping)

Example 10: 爱国主义始终是把中华民族坚强团结在一起的精神力量, 改革创新始终是鞭策我们在改革开放中 与时俱进的精神力量。(The First Public Speech by President Xi Jinping)

Example 11:这就是中国各族人民大团结的力量。中国梦是民族的梦，也是每个中国人的梦。(The First Public Speech by President Xi Jinping)

Example 9, 10 and 11 show Xi's relation processes mainly upholding the spiritual ideologies Chinese people need to remain committed to. It stresses patriotism, reform, and most importantly Chinese dream Chinese people should adhere to.

3. Mental process

From the distribution of mental process in Trump's and Xi's speeches illustrated by Table 2, 4.9\% in Trump's speech and 3.3 in Xi's speech are counted. Mental process can effectively influence audience's emotion. Both presidents use mental process to arouse their people's emotion. Meanwhile, there are some different connotations in their use of mental process. 
Example 12: The forgotten men and women of our country will be forgotten no longer. (The Inaugural address by President Donald Trump)

In this example, Trump uses mental processes to acclaim his empathy for his American citizens by using the sub-categorization of cognitive expression "will be forgotten no longer" as a bridge between the senser and the phenomenon.

Example 13: In America, we understand that a nation is only living as long as it is striving. (The Inaugural address by President Donald Trump)

In this example, the mental verb "understand" is used to convey Trump's thinking and opinion on his governance and the personal pronounce "we" is utilized to unconsciously bridge down the gap between himself and the public, enabling people to support his administration.

Example 14: 我深知, 担任国家主席这一崇高职务, 使命光荣, 责任重大。(The First Public Speech by President Xi Jinping)

In this example, President Xi uses “深知” to emphasize his responsibility as a President of china, conveying a positive image of his presidency for people. However, the personal pronounce “我” instead of “我们” is used, to some extend, weakening the relation between his presidency and the people.

4. Verbal process and existential process

Verbal process and existential process are rare to find in two speeches. In Xi's speech, there is no existence in the distribution of verbal process and existential process, which means the high-level of formality in Xi's speech. Only one verbal process used in Trump's speech is in the form of direct speech illustrated by the following example.

Example 15: The Bible tells us: "How good and pleasant it is when God's people live together in unity." (The Inaugural address by President Donald Trump)

In this example, trump uses Bible's quotation to enhance the credibility and reliability of his speech, making his speech more authoritative.

Existential process often is used to objectively describe the present situations, making the speech more concrete and convincing. However, the overuse of it will increase the dullness of the speech. Therefore, in the two speeches, existential process is scarce to find.

Example 16: There was little to celebrate for struggling families al across our land. (The Inaugural address by President Donald Trump)

Example 17: When you open your heart to patriotism, there is no room for prejudice. (The Inaugural address by President Donald Trump)

Example 18: But for too many of our citizens, a different reality exists. (The Inaugural address by President Donald Trump)

In the three examples of existential process, it is obvious that Trump objectively analyzes the present situations of America.

\section{Behavioral process}

Behavioral process is used to describe human physiological and psychological behaviors or activities, such as breathing, coughing, and simile, so there is little or no behavioral process in the two speeches.

Example 19: 我们要随时随刻倾听人民呼声...... (The First Public Speech by President Xi Jinping)

Example 20: The forgotten men and women of our country will be forgotten no longer. Everyone is listening to you now. (The Inaugural address by President Donald Trump)

Example 21: So to all Americans, in every city near and far, small and large, from mountain to mountain, and from ocean to ocean, hear these words: You will never be ignored again. (The Inaugural address by President Donald Trump)

From the above three examples of behavioral process used in the two speeches, the behavioral verbs like “倾听”, "listen" and "hear" are used to show the two presidents their sincere concerns for people's well-being.

\section{Ideological Differences between Trump's and Xi's Addresses}

This study is set to analyze the distribution and functions of the six transitivity process in the inaugural speeches of President Trump and President Xi Jinping, aiming to explore the similarities and differences between the two speeches in transitivity system of Systemic Functional Grammar and further to investigate ideological differences behind their speeches. Through statistical analysis, it is found that the distribution of six transitivity processes in the two speeches is generally consistent, in which material process has the highest frequency and relational process ranks second followed by mental process. The other three processes, that is, verbal, existential and behavioral processes rarely appear in the two discourses. There are some subtle differences in the three lower-frequency processes. Existential and verbal processes are nonexistent and only one behavioral process in Xi's discourse.

In general, the similarities in material process in the two discourses are due to the fact that Trump and $\mathrm{Xi}$ as new Presidents need to similar intentions, expressing their new ideas, clarifying their policies, caring people's needs and calling on their support. However, Xi's material processes more concerns of doing spiritual consolidation and socialism thought fortification instead of Trump's concrete action in physical American situations. In relational process, Trump's discourse inclines to use attributive type of relational process, physical depicting the relations between entities, while Xi's speech more tends to use classifying type of relational process, prescribing the relations between entities, mostly 
the thoughts and spirits. In mental process, Trump more likes to show his empathy for people to arouse their emotion. For $\mathrm{Xi}$, he shows his own concerns for himself, his responsibility, his thoughts and his determination. There is no verbal and existential processes in Xi's speech, showing, to some extent, the formality of the speech, making Xi's speech solemn and sublime. From the opposition, Trump needs to make references from Bible, tries to increase his closeness to his people and gains more support from the public. Nevertheless, in behavioral, both Presidents show their sincere for people's lives.

Due to the different cultural and political backgrounds, personal experiences and different intentions, the two presidents differ in their speeches and the choice of transitivity processes. As the only president in the United States with no political and military experience, Trump urgently needs to convince their people that he has the ability to lead the country to a prosperous and thriving future. The separation of power and the system of checks-and-balances in U.S.A. doom the presidency in America to people-inducing orientation. Presidents in America need to shape their positive, credible and authoritative images and make their speech more convincing and instigating for their people. Based on this, a quite number of material processes and relational processes of attributive type are used to describe physical presentation of America. Mental process is used to bridge down the psychological distance between presidency and the people. Quotations from Bible in verbal process try to make speech reasonable and impressive, for example in Trump's speech. For China, A President works as a leader of overall situations in spirit and thought, making our country running on the right track and on the move. Presidency in China does not need to induce and instigate people because our people are the country's solid foundation and our main source of confidence to govern. There is no need of disseminating the people reliance in presidency as a competitive advantage. Therefore, material processes and relational processes in Xi's speech mainly focus on the unity of though and spirit. In China, our party should lead all aspects of the country. The superiority of presidency also does not need to be shown by any references or quotation marks. Therefore, there is little verbal, behavioral and mental processes in China president speeches.

\section{CONCLUSION}

The study uses the transitivity process from Systemic Functional Grammar to explore the ideological differences between China and America by using two presidents, Trump's and Xi Jinping's inaugural speeches. It finds that material, mental and relational processes predominate both speeches and Xi's speech mainly takes the overall lead in spiritual guidance and inclines to generally control the economic and social development in China. For Trump, due to the political background in America, he needs to employ all his skill to induce and gain the supports from American people, objectively depicting American mediocre situations by material process, trying to narrow down the psychological distance between his governance and the people by mental process and increasing the belonging of American people by relational process. This paper provides people with a new perspective on political speeches, hoping to improve people's judgment when reading foreign and domestic political discourses, and further to enhance their understanding underlying ideological differences behind political speeches.

\section{REFERENCES}

[1] Dan Shen. (2006). Transitivity and hidden symbolic significance: Langston Hughes' "On the Road". Beijing: Foreign Language Teaching and Research (bimonthly), (1),4-11.

[2] Halliday, M. A. K. (1971). Linguistic function and literary style: An inquiry into the language of William Golding's the inheritors. London: Oxford University Press.

[3] Halliday, M. A. K. (1994). An Introduction to functional grammar. London: Edward Arnold.

[4] Halliday, M. A. K. (2004). An Introduction to Functional Grammar. London: Edward Arnold.

[5] Jing Gong\&Yan Fang. (2005). An Ideational Functional Analysis of Argumentative Discourse in English Courts. Nangjing: Foreign Language Research, 3, 11-16.

[6] Kondowe, W. (2014). Presidents and ideologies: A transitivity analysis of bingu wa mutharika's inaugural address. International Journal of Language and Linguistics, 3, 174-180.

[7] Li Wang. (2009). Transtivity Analysis of Amercian President Barack Obama's Inaugural Address. Master dissertation, Jilin University of China.

[8] Min Li. (2010). Transitivity Analysis of Franklin D. Roosevelt and Barack Obama's Inaugural Addresses. Master dissertation, Shangdong University of Science and Technology of China.

[9] Li Wen. (2013). Transitivity Analysis of American Presidential Inaugural Address. Master dissertation, Yangtze University of China.

[10] Min Li. (2010). Transitivity Analysis of Franklin D. Roosevelt and Barack Obama's Inaugural Addresses. Master dissertation, Shandong University of Science and Technology of China.

[11] White House. (2017). The Inaugural address delivered by President Donald Trump. https://www.whitehouse.gov/briefings-statements/the-inaugural-address/. (accessed 01/4/2019).

[12] Xinhua News. (2017). The First Public Speech delievered by President Xi Jinping in the 12th national people's congress. http://cpc.people.com.cn/n/2013/0318/c64094-20819130.html. (accessed 01/4/2019)

[13] Xueyan Yan. (2004). English Stylistic Features of International Political News. Nanjing: Foreign Language Research, 3, $31-37$.

[14] Yin Chen. (2008). Transitivity Analysis of 2005 American President Bush's Inaugural Speech. Journal of Xiangtan Normal University (Social Science Edition), 3, 107-109. 
Guohai Liao was born in Fujian, China in 1995. He is a postgraduate student majoring in Pragmatics, Discourse Analysis, and Systemic Functional Grammar in College of Foreign Languages, University of Shanghai for Science and Technology (USST).

Geling Han was born in China on March, 1967. She is both a professor and Vice President in College of Foreign Languages, University of Shanghai for Science and Technology. Her research interests include Pragmatics, neurolinguistics, cognitive linguistics, translation and Systemic Functional Grammar. 